\title{
The accuracy of field sex determination in the Common Whitethroat Sylvia c. communis
}

\author{
JONAS WALDENSTRÖM \& ULF OTTOSSON
}

Abstract

\begin{abstract}
The accuracy of field sex determination of Common Whitethroats captured during spring migration in Nigeria was tested with a genetic sex determination technique. Among both age classes males were more often correctly sexed than females. In total, one out of four birds were incorrectly sexed, and the ability to sex correctly varied considerably between ringers. Hence, a cautious attitude must be held at all times towards the use of field sex assessment in Common Whitethroats.
\end{abstract}

Jonas Waldenström, Ottenby fågelstation, Pl 1500, S-380 65 Degerhamn, Sweden and Animal Ecology/EBC, Norrbyvägen 18D, S-752 36 Uppsala, Sweden.

Ulf Ottosson, Department of Animal Ecology, Ecology Building, S-223 62 Lund, Sweden; present address 18A, rue de Mamer, L-8280 Kehlen, Luxemburg.

Received 10 February 2000, Accepted 22 February 2000, Editor: S. Bensch

\section{Introduction}

The determination of sex in Common Whitethroats in spring is difficult, since the sexes are only slightly sexually dimorphic in size and coloration. Some subtle differences have been described for determination of trapped birds (Cramp 1992, Svensson 1992). However, these criteria are vague and can be hard to correctly assess.

Recent advances in molecular biology have provided ecologists with new tools for sex determination of birds (Ellegren 1996, Griffiths et al. 1996, 1998, Fridolfsson \& Ellegren 1999). In this study we have determined the chromosomal sex of individual Common Whitethroats following Fridolfsson \& Ellegren (1999). This method uses the fact that, in birds, females are the heterogametic sex (ZW) while males are the homogametic (ZZ). Sex can therefore be determined by identifying the presence of a $\mathrm{W}$ chromosome. This method enables us to evaluate the accuracy of the criteria used for field sex determination in Common Whitethroats.

\section{Materials and methods}

The study area

Birds were trapped with mistnets in a semiarid Sahelian area $\left(13^{\circ} 33^{\prime} \mathrm{N}, 13^{\circ} 23^{\prime} \mathrm{E}\right)$ outside the town Mallamfattori in NE Nigeria, during the period between 2 and 24 April 1999. The study area was of a seminatural type and acted as a stop-over site for Common Whitethroats during spring migration.

\section{Ageing and sexing}

Birds were aged according to characters presented in Svensson (1992), Jenni \& Winkler (1994) and Karlsson et al. (1985), as either adult or 2Y (second calendar year). The five ringers were all experienced in general age and sex determination techniques, including the ringing of Common Whitethroats.

Sex was determined according to plumage, following criteria modified from Svensson (1992) and Cramp (1992). Adult birds having an ash-grey crown and forehead with none or just a few brown feathers admixed, throat white, breast with extensive 
pink tinge and pure white on the outer tail feathers were considered as males. Adult birds with completely brown crown and forehead, or brown with a few grey feathers admixed, throat white to cream-white, breast with less, or no, pink tinge were considered as adult females. $2 \mathrm{Y}$ birds with grey or greyish-brown crown and forehead, white throat and pink tinge on the breast were considered as males. $2 \mathrm{Y}$ birds with brown crown and forehead, creamywhite throat and little, or no, pink on the breast were considered as females. In contrast to Cramp (1992) this classification allows for adult females to have some grey feathers in the crown and the forehead. In some cases birds were not sexed due to either lack of time or uncertainty of the ringer.

\section{Genetic sexing}

Blood samples of approximately $20 \mu \mathrm{l}$ each were randomly sampled from some of the in total 653 trapped Common Whitethroats. The blood samples were stored in $500 \mu \mathrm{l}$ of $99.5 \% \mathrm{EtOH}$. Temperatures in the field were ambient, but later the samples were kept at below $8^{\circ} \mathrm{C}$.

DNA was extracted by standard molecular methods involving digestion by proteinase $\mathrm{K}$ and subsequent extraction with phenol and chloroform. The extracted DNA was resolved in $\mathrm{ddH}_{2} \mathrm{O}$ and the final concentration measured on a spectrophotometer.

The chromosomal sex of individuals was determined following Fridolfsson \& Ellegren (1999), where a pair of sexed-linked genes with a difference in intron length (CHD1W and CHD1Z) are detected with the $2550 F$ and $2718 R$ primers. The reactions were performed in a GeneAmp® PCR System 9700 in $10 \mu \mathrm{l}$ reaction volumes containing $1 x$ Perkin Elmer buffer II with no $\mathrm{MgCl}_{2}, 0.02 \mathrm{mM}$ dNTP, $3.25 \mathrm{mM}$ $\mathrm{MgCl}_{2}, 0.4 \mu \mathrm{M}$ of $2550 F$ primer, $0.4 \mu \mathrm{M}$ of $2718 R$ primer, $0.1 \mu \mathrm{l}$ of $2 \mathrm{U} / \mu \mathrm{l}$ AmpliTaq DNA Polymerase and between 3-50 ng of target DNA.

An initial denaturing step of $94^{\circ} \mathrm{C}$ for 3 min was followed by a "touch-down" scheme where the annealing temperature was lowered $1^{\circ} \mathrm{C}$ per cycle from $60^{\circ} \mathrm{C}$ until $50^{\circ} \mathrm{C}$ was reached. Then followed 27 cycles with a denaturing step of $94^{\circ} \mathrm{C}$ for $30 \mathrm{sec}$, an annealing step of $50^{\circ} \mathrm{C}$ for $30 \mathrm{sec}$ and an extension step of $72^{\circ} \mathrm{C}$ for $1 \mathrm{~min}$. PCR products were separated in $2 \%$ agarose gels using $0.5 \times \mathrm{TBE}$ buffer. The DNA was then visualised by ethidium bromide staining and UV-light. Female individuals yielded two bands and males one band on the gel.

\section{Results}

Comparison between plumage and genetically based sex determination was possible for 86 birds (Table 1). Errors in the sex determination was significantly more likely in $2 \mathrm{Y}$ females than in $2 \mathrm{Y}$ males $\left(\chi^{2}{ }_{1}=\right.$ $4.57, \mathrm{P}<0.05)$. In the small sample of adult birds, the numerical difference was in the same direction, with more incorrectly sexed females than males, however the difference was not significant $\left(\chi^{2}{ }_{1}=2.91\right.$, n.s. $)$.

As all the ringers, with the possible exception of ringer $\mathrm{E}$, had considerable experience of ringing Common Whitethroats and as well were using the same reference literature, the differences in ability to sex the birds correctly (Table 2) is somewhat surprising.

Table 1 . The numbers of in the field correctly and incorrectly sexed Common Whitethroats, the number of previously unsexed (plumage based) and the percentage of correctly sexed individuals.

Antalet i fält korrekt könsbestämda törnsångare, antalet felaktigt könsbestämda individer, antalet individer som ej könsbestämdes med dräktkaraktärer och procentsatsen korrekt könsbestämda törnsångare.

\begin{tabular}{llll} 
Adult males & Adult females & $2 \mathrm{Y}$ males & $2 \mathrm{Y}$ females \\
Adulta hanar & Adulta honor & 2 K hanar & 2 Khonor \\
\hline
\end{tabular}

\section{Correctly sexed}

Korrekt könsbestämda

Incorrectly sexed

Felaktigt könsbestämda

1

5

5

Unsexed

Icke könsbestämda

1

$-$

4

6

$\%$ correctly sexed

\% korrekt könsbestämda
$80 \%$ 


\section{Discussion}

Sexing of Common Whitethroats is a very difficult task, even for persons with long experience in general age and sex determination techniques in passerine birds (Svensson 1992). In this study, the criteria allowed correct identification of most males. Females were on the other hand more often incorrectly sexed. It is remarkable that the success in identifying females is no better than had sex been assigned randomly. This result is surprising since we allowed adult females to display also some grey feathers in the crown, a feature which is thought only to be expressed in males (Cramp 1992). It is evident that some females were very male-like, thus precluding correct sexing according to plumage. Males on the other hand rarely look like typical females. Sex differences within the Sylvia genera are generally slight (Svensson 1992), and old females of some species, e.g. Subalpine Warbler S. cantillans, Sardinian Warbler $S$. melanocephala and Barred Warbler $S$. nisoria seem to attend a more male-like plumage with age (Svensson 1992).

The suggested field sex determination criteria to be used in hand are not reliable. Between population variation in plumage coloration is likely to diminish the sexing success rate even further. Hence sex determination of Common Whitethroats must be done with great care: it is only advisable to sex typical individuals, especially female looking individuals are most likely females, whereas "typical males" might include some females. Since Common Whitethroats are only rarely trapped in large numbers at any single site a cautious attitude is advisable at all times. If any uncertainty remains after examining a bird, it is most advisable to leave the bird unsexed.

\section{Acknowledgement}

This article is based on data collected for a master thesis in biology, written at the department for Animal Ecology at Uppsala. We are very thankful to Mats Björklund and Ben Sheldon for providing laboratory facilities and support. We also thank Staffan Bensch for advice and suggestions on a draft of this manuscript. At last we would like to thank members and staff of the Lake Chad Bird Migration Project, especially Franz Bairlein, Phil Hall, Christian Hjort, Stephen Rumsey and Fernando Spina. A special thanks goes to A. P. Leventis, who gave logistical and financial support. The Swedish participants were funded through a grant from the Hasselblad foundation. This is report no. 169 from Ottenby Bird Observatory.

\section{References}

Cramp, S. (ed). 1992. The Birds of the Western Paleartic. Vol. VI. Oxford University Press. Oxford

Ellegren, H. 1996. First gene on the avian W chromosome (CHD) provides a tag for universal sexing of non-ratite birds. Proc. R. Soc. Lond. B 263: 1635-1641

Fridolfsson, A.-K. \& Ellegren, H. 1999. A simple and univer-

Table 2. Differences between ringers in the number of correctly sexed, incorrectly sexed and unsexed Common Whitethroats, when plumage based sexing was checked through genetic sexing. Also noted are the total numbers of ringed birds by each ringer and the percentage correctly sexed and incorrectly sexed birds.

Skillnader mellan de olika ringmärkarna i antalet korrekt könsbestämda, antalet felaktigt könsbestämda samt antalet ej könsbestämda törnsångare när den fjäderdräktsbaserade könsbestämningen korrigerats mot den genetiska bestämningen. I tabellen ses även det totala antalet fåglar, procentandelen korrekt könsbestämda och procentandelen felaktigt könsbestämda individer.

\begin{tabular}{llllcc}
\hline Ringer Märkare & A & B & C & D & E \\
\hline Correctly sexed Korrekt könsbestämda & 17 & 14 & 15 & 6 & 1 \\
Incorrectly sexed Felaktigt könsbestämda & 3 & 2 & 9 & 6 & 2 \\
Unsexed Icke könsbestämda & 5 & 3 & 1 & 2 & - \\
Total numbers Totalt antal & 25 & 19 & 25 & 14 & 3 \\
\% correctly sexed korrekt könsbestämda & $68 \%$ & $74 \%$ & $60 \%$ & $43 \%$ & $33 \%$ \\
\% incorrectly sexed felaktigt könsbestämda & $12 \%$ & $11 \%$ & $36 \%$ & $43 \%$ & $67 \%$ \\
\hline
\end{tabular}


sal method for molecular sexing of non-ratite birds. Journal of Avian Biology 30: 116-121

Griffiths, R., Daan, S. \& Dijkstra, C. 1996. Sex identification in birds using two CHD genes. Proc. R. Soc. Lond. B 263: 1251-1256

Griffiths, R., Double, M. C., Orr, K. \& Dawson, J. G. 1998. A DNA test to sex most birds. Molecular Ecology 7: 10711076

Jenni, L. \& Winkler, R. 1994. Moult and ageing of European Passerines. Academic Press. London

Karlsson, L., Persson, K. \& Walinder, G. 1985. Fotografisk dokumentation av ålders- och könsskillnader hos fåglar målsättning, arbetssätt och exempel på resultat. Vår fågelvärld 44: 465-478

Svensson, L. 1992. Identification Guide to European Passerines. 4th Ed. Stockholm: Lars Svensson

\section{Sammanfattning}

Tillförlitligheten av dräktbaserad könsbestämning av törnsångare Sylvia c. communis

Att könsbestämma törnsångare i samband med ringmärkning är svårt eftersom könen skiljer sig ytterst lite åt i morfologi och teckning. En del fjäderdräktsbaserade karaktärer finns beskrivna av Cramp (1992) och Svensson (1992), vilka ofta används praktiskt i ringmärkningssammanhang. Tillförlitligheten av dessa karaktärer har tidigare varit svår att testa, men med hjälp av nya genetiska metoder har detta förhållande ändrats. I den här artikeln använder vi en genetisk könsbestämningsmetod (Fridolfsson \& Ellegren 1999) för att utvärdera den dräktbaserade bestämningen.

\section{Material och metoder}

Fåglarna fångades i samband med ringmärkning nära staden Mallamfattori $\left(13^{\circ} 33^{\prime} \mathrm{N}, 13^{\circ} 23^{\prime} \mathrm{E}\right)$ i nordöstra Nigeria. Fåglarna åldersbestämdes till adulta eller $2 \mathrm{~K}$ (andra kalenderåret) med hjälp av kriterier från Svensson (1992), Jenni \& Winkler (1994) och Karlsson et al. (1985). Dräktbaserad bestämning gjordes i handen utifrån karaktärer modifierade från Svensson (1992) och Cramp (1992). Adulta hanar, definieras i den här studien som fåglar med helt grå hjässa, eller grå hjässa med några bruna fjädrar insprängda, rent vit haka, rosa färgat bröst och rent vita partier på de yttre stjärtpennorna. Adulta honor hade brun hjässa, eller brun med några grå fjädrar inblandade, vit haka och bröst med lite eller ingen rosa ton. $2 \mathrm{~K}$ hanar hade grå eller gråbrun hjässa, vit haka och rosa färgat bröst. $2 \mathrm{~K}$ honor hade brun hjässa, gräddvit haka och ett bröst som saknade eller endast i mindre utsträckning hade en rosa ton.

Den genetiska könsbestämningen grundar sig på att det hos fåglar är honorna som är det heterogameta könet (ZW) medan hanarna är det homogameta (ZZ). Könet kan därmed bestämmas genom att identifiera W-kromosomen, som endast honan bär. I den här studien användes ett könsbundet gen-par (CHD1W och CHD1Z) som skiljer sig åt i intronstorlek. Denna storleksskillnad kan åskådligöras med hjälp av PCR och ett särskilt primerpar (2550F och 2718R). PCR-produkten separeras med elektrofores och synliggörs med etidiumbromid och UVljus. Honor ger upphov till två band på gelen medan hanarna endast ger ett.

\section{Resultat}

Sammanlagt testades 86 individer (Tabell 1). Det gjordes signifikant fler fel i könsbestämningen av $2 \mathrm{~K}$ honor än $2 \mathrm{~K}$ hanar, och samma tendens fanns, om än icke signifikant, hos adulta fåglar. Korrektheten vid könsbestämningen varierade mellan ringmärkarna (Tabell 2).

\section{Diskussion}

Med de kriterier som användes i den här studien kunde de flesta hanar könsbestämmas korrekt. Honor däremot blev ofta felbestämda, mönstret liknar det som skulle ha uppkommit om könet bestämdes enbart med slumpens hjälp. Detta trots att vi tillät en något generösare tolkning av hjässans färger vad gäller adulta honor än vad som görs av Cramp (1992), och att alla ringmärkare var erfarna och vana vid ålders- och könsbestämning av tättingar. Det är tydligt att en del honor var mycket hanlika i utseendet. Könsskillnader inom släktet Sylvia är ofta ringa (Svensson 1992), och hos en del arter, t. ex. rödstrupig sångare $S$. cantillans, sammetshätta $S$. melanocephala och höksångare $S$. nisoria kan äldre honor utveckla en mer hanlik fäderdräkt (Svensson 1992).

De karaktärer som idag finns till förfogande (i Cramp 1992 och Svensson 1992) för könsbestämning av törnsångare är inte tillräckliga för en säker bestämning. Karaktärernas värde minskar ytterligare om den individuella variationen är stor mellan populationer. Eftersom törnsångare sällan fångas i större antal på någon enskild ringmärkningslokal som erbjuder rikligt med jämförelse, bör man iaktta stor försiktighet vid könsbestämningen: endast typiska individer bör könsbestämmas, och man bör dessutom ha den låga tillförlitligheten i åtanke vid vidare analyser av ringmärkningsdata. 